УДК 343.13

DOI https://doi.org/10.32837/pyuv.v0i1.743

\author{
О.О. Лісовий \\ orcid.org/0000-0002-7758-2809 \\ аспірант кафедри права та публічного адміністрування \\ Маріупольського державного університету
}

\title{
УДОСКОНАЛЕННЯ СУДОВОГО КОНТРОЛЮ ЗА ПРОВЕДЕННЯМ НСРД, ПОВ'ЯЗАНИХ ІЗ ВИКОРИСТАННЯМ ТЕХНІЧНИХ ЗАСОБІВ: ПРОЦЕСУАЛЬНО-ПРАВОВИЙ АСПЕКТ
}

Постановка проблеми. Важливим критерієм верховенства права є ефективний судовий контроль, який передбачає відповідні контрольні процедури та механізми, що реалізуються судом із метою запобігання свавіллю органів виконавчої влади $[1$, с. 37$]$. Під час здійснення судового контролю за дотриманням законності у кримінальному провадженні робота суду характеризується здатністю активно впливати на дії та рішення суб'єктів кримінального процесу. Особливо важливим є здійснення контролю під час проведення негласних слідчих (розшукових) дій (далі - НСРД), пов'язаних із використанням технічних засобів, оскільки вони часто пов'язані з обгрунтованим втручанням у приватне життя осіб, тимчасовим обмеженням конституційних прав і свобод громадян.

Аналіз останніх досліджень. Питання отримання доказової та криміналістично значущої в кримінальному судочинстві інформації розглядали О.М. Бандурка, Є.А. Доля, С.В. Єськов, В.П. Захаров, Л.М. Лобойко, В.З. Лукашевич, Є.Д. Лук'янчиков, Д.Й. Никифорчук, В.Л. Ортинський, Д.П. Письменний, М.А. Погорецький, Д.Б. Сергєєва, Є.Д. Скулиш, В.М. Тертишник, Л.Д. Удалова, І.Ф. Хараберюш, Р.М. Шехавцов, M.Є. Шумило та інші.

Проблематику використання технічних засобів під час протидії злочинності, у тому числі в межах проведення НСРД, досліджували В.І. Василинчук, М.Л. Грібов, В.Ю. Калугін, М.В. Корнієнко, Д.Й. Никифорчук, В.Л. Ортинський, І.В. Пиріг, Д.Б. Сергєєва, В.М. Тертишник, В.Г. Уваров, І.Ф. Хараберюш, I.P. Шинкаренко, О.О. Юхно та ін. Дослідженню питань здійснення судового контролю у кримінальному провадженні присвятили свої роботи І.В. Гловюк, М.В. Багрій, В.В. Городовенко, Ю.М. Грошевий, О.В. Кондратьєв, М.А. Макаров, В.І. Маринів, В.В. Назаров, М.А. Погорецький, О.І. Полюхович, В.О. Попелюшко, О.Ю. Татаров, А.Р. Туманянц, Л.Д. Удалова, О.Г. Шило та ін. Кожен із учених зробив важливий внесок у вирішення проблем, що стоять перед сучасним науковим співтовариством.

Однак не всі проблемні питання судового контролю за проведенням НСРД охоплені у працях названих авторів. Поза увагою залишається чимало аспектів, що стосуються оптимізації процедури судового санкціонування НСРД, пов'язаних із використанням технічних засобів. Недостатня наукова розробленість теорії, а також існуючі організаційні проблеми зумовили необхідність проведення цього дослідження. Мета статті - дослідження проблем правового регулювання судового контролю під час проведення НСРД, пов'язаних із використанням технічних засобів, а також розроблення пропозицій з удосконалення чинного кримінального процесуального законодавства в цій cфеpi.

Виклад основного матеріалу. Згідно з вимогами кримінального процесуального закону, виключно слідчий суддя приймає рішення про обмеження конституційних прав, а КПК суворо регламентує процедуру прийняття такого рішення. Цей процесуальний порядок (механізм), з одного боку, сприяє результативності й ефективності застосування передбачених законом заходів, а з іншого - максимально забезпечує дотримання прав, свобод та інтересів осіб, до яких вони застосовуються, захищаючи їх від надмірного, неприпустимого примусу [2, с. 58]. Водночас недосконалість судово-дозвільної діяльності в контексті недопущення безпідставних обмежень прав громадян підкреслюється непоодинокими випадками судових відмов у задоволенні клопотань. Так, за даними Генеральної прокуратури України впродовж 2020 року до слідчих суддів надійшло 159366 клопотань суб'єктів розслідування щодо проведення НСРД. За результатами розгляду клопотань судами задовільнено 147 888, відмовлено в задоволенні - 11478 [3].

Відповідно до ч. 3 ст. 248 КПК слідчий суддя постановляє ухвалу про дозвіл на проведення НСРД, якщо прокурор, слідчий доведе наявність достатніх підстав вважати, що: 1) вчинене кримінальне правопорушення відповідної тяжкості; 2) під час проведення НСРД можуть бути отримані докази, які самостійно або в сукупності з іншими доказами можуть мати суттєве значення для з'ясування обставин кримінального правопорушення або встановлення осіб, які вчинили кримінальне правопорушення.

Згідно з вимогами п. 9 ч. 2 ст. 248 КПК України клопотання має містити обгрунтування 
можливості отримання під час проведення НСРД доказів, які самостійно або в сукупності з іншими доказами можуть мати суттєве значення для з'ясування обставин злочину або встановлення осіб, які його вчинили [4, с. 80-81].

Під час складання клопотання слідчому (прокурору) необхідно прийняти багатоаспектне рішення, врахувати всі обставини кримінального правопорушення, цілі розслідування, прорахувати перспективу отримання фактичних даних та їх легалізації як доказів. Роль слідчого судді в дослідженні доказів є активною і витікає з таких положень КПК України: не можуть бути визнані доказами відомості, що містяться в показаннях, речі і документи, які не були предметом безпосереднього дослідження суду (ст. 23 КПК); суд за своїм внутрішнім переконанням, яке грунтується на всебічному, повному й неупередженому дослідженні всіх обставин кримінального провадження, керуючись законом, оцінює кожний доказ 3 погляду належності, допустимості, достовірності, а сукупність зібраних доказів - щодо достатності та взаємозв'язку для прийняття відповідного рішення (ст. 94 КПК); судове рішення повинно бути законним, обгрунтованим і вмотивованим (ст. 370 КПК). Відповідно до ч. 4 ст. 248 КПК, ухвала слідчого судді про дозвіл на проведення НСРД має відповідати загальним вимогам, що пред'являються до судових рішень.

Невідповідність змісту клопотання положенням ч. 3 ст. 248 КПК України автоматично тягне за собою відмову в надані дозволу на проведення НСРД. Слідчий суддя виносить ухвалу про відмову в надані дозволу на проведення НСРД і тоді, коли клопотання щодо проведення НСРД не відповідає встановленим процесуальним вимогам [5, с. 313]. Досить часто ініціатор просто уникає зазначення в клопотанні всіх обставин, що надають обгрунтовані підстави підозрювати особу у вчиненні злочину, мають значення для розгляду клопотання по суті. Крім того, слід ураховувати, що на момент звернення з клопотанням ініціатору не завжди відома вся необхідна інформація. Особливо це стосується конкретної інформації про об’єкта НСРД (наприклад, відомості про особу, яка користується кінцевим обладнанням телекомунікацій).

Постановлення ухвали про відмову в наданні дозволу на проведення НСРД не перешкоджає повторному зверненню з новим клопотанням про надання такого дозволу (ч. 5 ст. 248 КПК). Своєю чергою повторне звернення з новим клопотанням щодо проведення НСРД (ч. 5 ст. 248 КПК України) на практиці не обов' язково передбачає врахування попередніх зауважень, які слугували підставою для відмови у задоволенні попереднього клопотання, що призводить до зловживань з боку суб’єктів кримінального провадження [6]. Часто ініціатори НСРД повторно подають те ж саме клопотання, не усунувши недоліки, які ставали причиною попередньої відмови в його задоволенні. Нерідкими є випадки, коли при повторних зверненнях із клопотанням щодо проведення НСРД, пов'язаних із використанням технічних засобів, слідчий не зазначав суттєві установчі дані, які мають ключове значення для проведення НСРД. Іноді доходить до того, що при повторному зверненні з клопотанням щодо проведення такого НСРД, як установлення місцезнаходження радіоелектронного засобу (ст. 268 КПК України), слідчі забувають вказувати ідентифікаційні ознаки, які б дозволяли унікально ідентифікувати абонента (об'єкта).

3 цього приводу I.I. Башта слушно зазначає, що право повторного звернення з тим самим клопотанням про дозвіл на проведення НСРД може призвести до зловживань з боку слідчих, порушень прав особи, а також ставить під сумнів обІрунтованість і необхідність проведення таких дій. Науковець пропонує змінити ч. 5 ст. 248 КПК, закріпивши за слідчим право звернутися 3 повторним зверненням із новим клопотанням за умови усунення обставин або недоліків, вказаних слідчим суддею в ухвалі про відмову в задоволенні клопотання про надання дозволу на проведення негласних слідчих (розшукових) дій [7, с. 174].

Загалом вважаємо за необхідне звертати увагу на повноту викладення обставин та установчих даних під час звернення з клопотанням щодо проведення НСРД, пов'язаних із використанням технічних засобів. Забезпечити виконання цього завдання можна лише шляхом внесення відповідних змін до кримінального процесуального закону. Так, законопроектом № 8555 від 04.07.2018 було запропоновано внести зміни до ст. 248 КПК, згідно з якими слідчий та прокурор не мали би права повторно звертатися до слідчого судді з клопотанням про дозвіл на проведення НСРД, якщо б у клопотанні не були зазначені нові обставини, які не розглядалися слідчим суддею [8].

Однак ми вважаємо наведене вище формулювання не зовсім точним. По-перше, щодо терміна «нові обставини» або «нововиявлені обставини». У процесуальному праві це узагальнена категорія юридичних фактів, які мають суттєве значення для вирішення справи по суті, але не були відомі суду та іншим учасникам процесу на момент ухвалення рішення, внаслідок чого було допущено судову помилку. Необхідними ознаками нововиявлених обставин є одночасна наявність таких умов: 1) їх існування на час розгляду; 2) ці обставини не могли бути відомі заявникові на час розгляду; 3) істотність цих обставин для розгляду [9, с. 511].

У розумінні п. 4 ч. 2 ст. 459 КПК це такі обставини, що не були відомі під час ухвалення судового рішення і які самі по собі або разом із раніше виявленими обставинами доводять неправильність вироку чи ухвали. 
Таким чином, прив'язка можливості подання клопотань щодо НСРД виключно до виникнення (відкриття) нових обставин є обмеженням прав суб'єктів кримінального провадження.

По-друге, випадки подання відносно законних, але недостатньо обгрунтованих клопотань про проведення НСРД у діяльності слідчих суддів є досить частим явищем. Це відбувається через непрофесійність ініціаторів, які не зібрали досить доказів або склали матеріали з порушенням процесуальних вимог. Якщо саме проведення НСРД є необхідним та обґрунтованим, то після якісної підготовки матеріалів, збору доказової бази, виконання всіх процесуальних вимог ініціаторові, керуючись ч. 5 ст. 248 КПК, доречно звернутись із клопотанням повторно. Слідчий суддя, оцінивши всі доводи, наведені в такому клопотанні, враховуючи характер злочинних дій, обгрунтованість підстав, наявність перспектив отримання позитивного результату, безсумнівно, повинен його задовольнити.

Ключовим критерієм, за яким можна розмежувати відносно законні (недостатньо обгрунтовані) клопотання від абсолютно незаконних, є відсутність за останніми достатніх підстав для проведення НСРД взагалі. Натомість за першою групою клопотань безпосереднє проведення НСРД є необхідним і законним, а тому має бути здійснене на законних підставах після виправлення всіх процесуальних помилок, допущених раніше ініціатором $з$ якихось причин (некомпетентність, відсутність даних тощо).

На нашу думку, в разі, якщо подається клопотання, позитивне вирішення якого тягне за собою проведення безпідставних незаконних НСРД, що порушують конституційні права громадян, результат вирішення такого клопотання має бути однозначно негативним. I навіть зазначення в повторному клопотанні якихось нових обставин, які ще не розглядалися слідчим суддею, не робить проведення самих НСРД необхідним, обгрунтованим та допустимим.

Повторне клопотання передбачає дослідження слідчим суддею в сукупності як нових, так і попередніх обставин (тобто повторне дослідження фактичних даних). При цьому важко однозначно відповісти на запитання, трудомісткість розгляду якого клопотання є більшою: безпідставного (незаконного) або клопотання, поданого з порушеннями процесуальних вимог. Тут мають значення різні чинники.

Натомість із упевненістю можна сказати, що за загальним правилом повторне дослідження доказів визнається правом, а не обов'язком суду. Зокрема, позиція Верховного Суду в справі № 712/2341-к грунтувалася на правомірності відмови суду в задоволенні клопотання щодо повторного дослідження доказів, зумовленої відсутністю в поданому ініціатором клопотанні аргументованих підтверджень щодо необхідності цих дій [10].

Ми вважаємо, що заборона подання повторних клопотань, які не містять аргументованих підтверджень щодо необхідності такого розгляду (перегляду обставин, що слугували відмовою в задоволенні попереднього клопотання), з огляду на відсутність перспектив позитивного вирішення клопотання по суті, буде спонукати ініціаторів більш кваліфіковано і професійно підходити до складання та збору матеріалів.

Ще однією важливою проблемою в контексті правового регулювання судового контролю під час проведення НСРД, пов'язаних із використанням технічних засобів, є необхідність оптимізації строків розгляду клопотань з метою більш ретельного їх розгляду. Під час розгляду таких клопотань слідчий суддя має вивчати такі обставини, ЯК: законність ініціювання НСРД; процесуальна необхідність проведення НСРД; гарантії невтручання у приватне життя інших осіб; збалансованість обсягу проведення НСРД з урахуванням вчиненого і можливість використання інших доказів; впевненість у тому, що інформація буде отримана від конкретної особи [11, с. 152]. У зв'язку з цим вважаємо необхідним збільшити термін розгляду клопотання щодо проведення НСРД до 24 годин, протягом яких слідчий суддя матиме фізичну можливість здійснити повноцінний аналіз поданих йому матеріалів та визначити необхідність застосування конкретної НСРД та конкретного технічного засобу.

Висновки. 3 метою оптимізації процедури судового санкціонування НСРД, пов'язаних із використанням технічних засобів, слід звертати особливу увагу на повноту викладення ініціаторами клопотань обставин та установчих даних при поданні клопотань слідчому судді. Фільтрування клопотань щодо проведення НСРД, які не містять аргументованих підтверджень щодо необхідності такого розгляду (перегляду обставин, що слугували відмовою в задоволенні попереднього клопотання), з огляду на відсутність перспектив позитивного вирішення клопотання по суті, є необхідною мірою У справі забезпечення виконання завдань кримінального провадження.

Повторне дослідження доказів апріорі є правом, а не обов'язком суду. Водночас шодо клопотань про проведення НСРД законодавець встановив інший процесуально-правовий режим. У цих умовах забезпечити якісне виконання завдань кримінального провадження можливо шляхом врегулювання відповідних положень на законодавчому рівні. 3 урахуванням наведеного, ст. 248 КПК необхідно доповнити частиною шостою такого змісту:

«При повторному зверненні слідчим або прокурором із новим клопотанням про надання дозво- 
лу на проведення НСРД у клопотанні додатково зазначаються:

- обставини та установчі дані, які попередньо ще не розглядалися слідчим суддею, але мають безпосереднє значення для постановлення ухвали по суті заявленого клопотання;

- підтвердження усунення обставин, що слугували відмовою в задоволенні попереднього клопотання, або аргументовані доводи щодо необхідності перегляду таких обставин» .

\section{Jimepamypa}

1. Пухтецька А.А. Принцип верховенства права: сучасні європейські доктрини як орієнтир для реформування національного законодавства. Вісник НАН України. 2010. № 3. С. 33-43.

2. Назаров В.В. Конституційні права людини та ïх обмеження у кримінальному процесі України : монографія. Харків: ІД «Золота миля», 2009. 400 с.

3. Звіт про роботу прокурора за січень-грудень 2020 року (форма № П, затв. наказом Генерального прокурора України від 18.11.2015 № 350). URL: https://www.gp.gov.ua/ua/stat_n_st? m=fslib\& $\mathrm{t}=$ fsfile\&_c=download\&file_id $=2109 \overline{17}$ (дата звернення: 10.03 .2021 ).

4. Шум В. В. Накладення арешту на кореспонденцію у кримінальному судочинстві України : дис.... канд. юрид. наук. 12.00.09. Київ, 2014. 205 с.

5. Шерудило В. О. Судовий контроль під час проведення негласних слідчих (розшукових) дій, пов'язаних з втручанням у приватне спілкування. Право і суспільство. 2018. № 3. Ч. 2. С. 310-315.

6. Пропонується врегулювати порядок розгляду клопотань про надання дозволу на проведення негласних слідчих дій. URL: https://loyer.com.ua/ uk/proponuyetsya-vregulyuvati-poryadok-rozglyaduklopotan-pro-nadannya-dozvolu-na-provedennyaneglasnih-slidchih-dij (дата звернення: 09.01.2020).

7. Башта I.I. Удосконалення порядку розгляду клопотань про надання дозволу на проведення негласних слідчих (розшукових) дій. Актуальні проблели вітчизняної юриспрудениії. 2019. Вип.1. С. 172-175.

8. Рішення Європейського Суду від 15.05.1986 у справі № 222/84 «Джонстон проти головного констебля Королівської поліції Ольстера» European Court reports. 1986. P. 01651. URL: https://eur-lex.europa. eu/LexUriServ/LexUriServ.do?uri=CELEX:61984CJ02 22:EN:HTML (дата звернення: 10.03.2021).

9. Юридична енциклопедія : у 6 т. / відп. ред. Ю. С. Шемшученко. Київ : Українська енциклопедія ім. М. П. Бажана, 2002. T. 4.720 с.

10. Постанова Касаційного кримінального суду Верховного Суду України від 10.06.2020 за судовим провадженням № 51-6364км19. URL: https://reyestr.court.gov.ua/Review/89819681 (дата звернення: 10.03.2021).

11. Тагієв С. Процесуальні дії слідчого судді при наданні дозволу на проведення негласних слідчих (розшукових) дій. Слово Національної школи суддів України. 2013. № 4. С. 145-155.

\section{Анотація}

Лисовий О. О. Удосконалення судового контролю за проведенням НСРД, пов'язаних із використанням технічних засобів: процесуально-правовий аспект. - Стаття.

У статті розглянуто проблематику судового контролю при проведенні негласних слідчих (розшукових) дій, пов' язаних із використанням технічних засобів. Автор доводить, що норми національного законодавства, що регламентують процедури судового контролю під час здійснення кримінального провадження, в тому числі під час проведення негласних слідчих (розшукових) дій, пов' язаних з використанням технічних засобів, повинні будуватися з урахуванням непорушності європейських стандартів і принципів у сфері захисту конституційних прав і свобод людини. 3 метою вдосконалення чинного законодавства 3 питань судового контролю під час проведення негласних слідчих (розшукових) дій, пов'язаних з використанням технічних засобів, пропонується внести відповідні зміни до законодавства України.

У статті здійснюється умовне розмежування незадоволених клопотань щодо проведення негласних слідчих (розшукових) дій за критерієм наявності достатніх підстав для проведення цих дій на відносно законні (недостатньо обгрунтовані) та абсолютно незаконні (безпідставні). Автор зазначає, що в разі якщо подане недостатньо обгрунтоване клопотання, але проведення НСРД є об'єктивно необхідним, таке НСРД має бути здійснене на законних підставах при повторному поданні клопотання після виправлення всіх процесуальних помилок, допущених раніше ініціатором 3 якихось причин (некомпетентність, відсутність даних тощо). Автор доводить, що фільтрування клопотань щодо проведення НСРД, які не містять аргументованих підтверджень щодо необхідності такого розгляду, з огляду на відсутність перспектив позитивного вирішення клопотання, є необхідною мірою у справі забезпечення виконання завдань кримінального провадження. Обгрунтовується необхідність удосконалення положень чинного Кримінального процесуального кодексу України в частині забезпечення повноти викладу обставин і настановних даних при повторному зверненні з клопотанням про проведення НСРД, пов'язаних з використанням технічних засобів. Особлива увага приділяється питанню оцінки отриманих під час проведення НСРД фактичних даних на предмет законності (допустимості).

Ключові слова: правове регулювання, негласні слідчі (розшукові) дії, слідчий суддя, суд, судовий контроль, технічні засоби.

\section{Summary}

Lisovyy 0 . O. Improving judicial control over the implementation of NSDS related to the use of technical means: procedural and legal aspect. - Article.

The article considers the issue of judicial control during covert investigative (search) actions related to the use of technical means. The author argues that the rules of national law governing judicial review procedures in criminal proceedings, including the conduct of covert investigative (investigative) actions involving the use of technical means, should be based on the inviolability of European standards and principles in the field of protection constitutional human rights and freedoms. In order to improve the current legislation on judicial control in the conduct of covert investigative (search) actions related to the use of technical means, it is proposed to make appropriate changes to the legislation of Ukraine.

The article makes a conditional distinction between unsatisfied requests for covert investigative (search) actions on the basis of sufficient grounds for conducting these actions on relatively legal (insufficiently substantiated) and completely illegal (unfounded). The author notes that if an insufficiently substantiated request is submitted, but the NRSD is objectively 
necessary, such NRSD should be carried out legally when re-submitting the application after correcting all procedural errors previously made by the initiator for some reason (incompetence, lack of data, etc). The author argues that filtering NSDP motions that do not contain substantiated evidence of the need for such consideration, given the lack of prospects for a positive resolution of the petition, is a necessary measure in ensuring the implementation of criminal proceedings. The necessity of improving the provisions of the current
Criminal Procedure Code of Ukraine in terms of ensuring the completeness of the statement of circumstances and guidelines when re-applying for NSDS related to the use of technical means is substantiated. Particular attention is paid to the assessment of the actual data obtained during the NSDS on the subject of legality (admissibility).

Key words: legal regulation, covert investigative (search) actions, investigating judge, court, judicial control, technical means. 